\title{
Catéter doble J calcificado
}

\author{
J. Rodríguez Corchero, J. Leal Arenas, N. Cruz Navarro, F. Torrubia Romero, \\ P. Montañés Medina
}

Servicio de Urología. Hospital Universitario Virgen del Rocío. Sevilla.

Actas Urol Esp 2005; 29 (7): 722

$\mathrm{P}$ aciente varón de 68 años con antecedentes de litiasis ureteral derecha hace dos años tratada en otro hospital que acude a nuestras consultas por infecciones urinarias de repetición. Previamente había acudido a urgencias de nuestro hospital por este mismo motivo, habiéndosele realizado analíticas de sangre (normales) y orina (leucocituria + hematuria), así Ecografía abdominal (litiasis vesical y en riñón derecho).

Se realiza Rx simple de aparato urinario en la que se objetiva un catéter doble $\mathrm{J}$ calcificado en su totalidad (Fig. 1), con un gran cálculo en pelvis renal derecha y otro en vejiga (extremos del catéter). Ante estos hallazgos se realiza Urografia iv (Fig. 2) en la que ambos riñones son funcionantes.

Se propuso intervención quirúrgica reglada (Pielolitotomía + Cistolitotomía + extracción de catéter) que el paciente aceptó en principio, aunque no ha vuelto por nuestras consultas, siéndonos imposible localizarlo.

Dr. Rodríguez Corchero

C/ Cueva del Gato nํㅜ, Bloque 6, $3^{\circ} \mathrm{A}$

41020 - Sevilla

e-mail: jrcorchero@hotmail.com

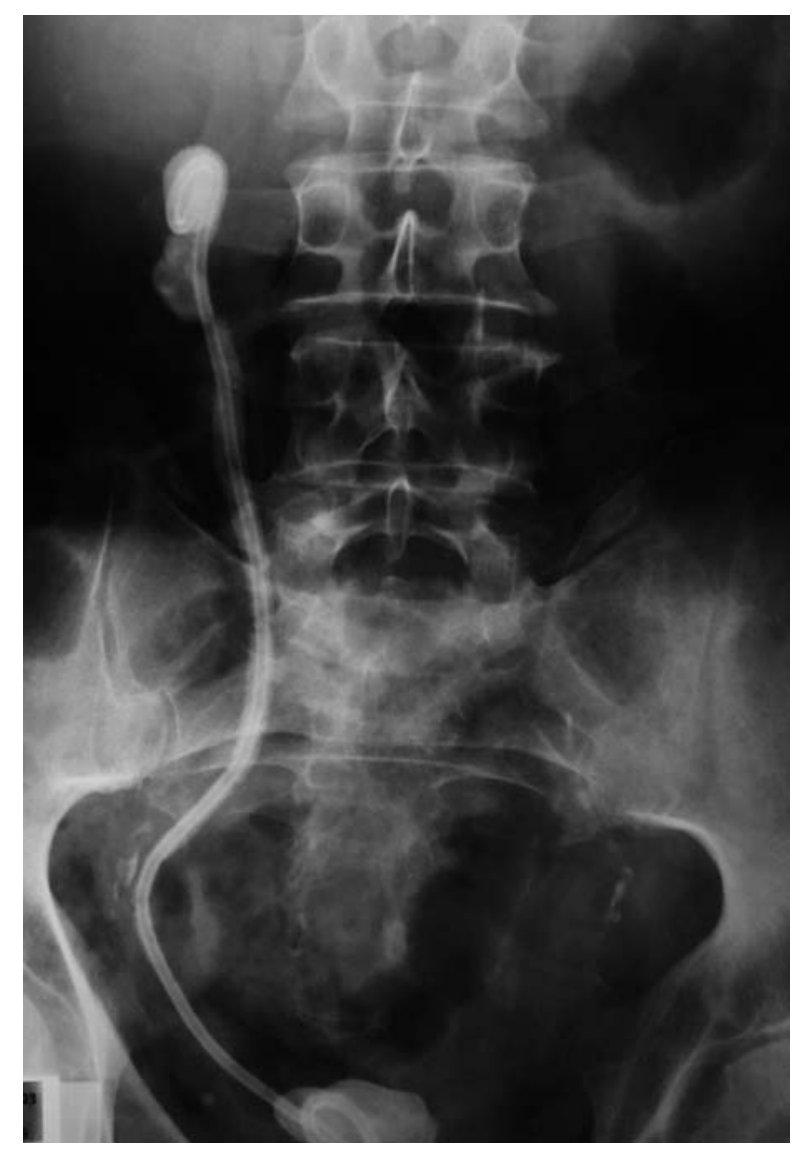

FIGURA 1
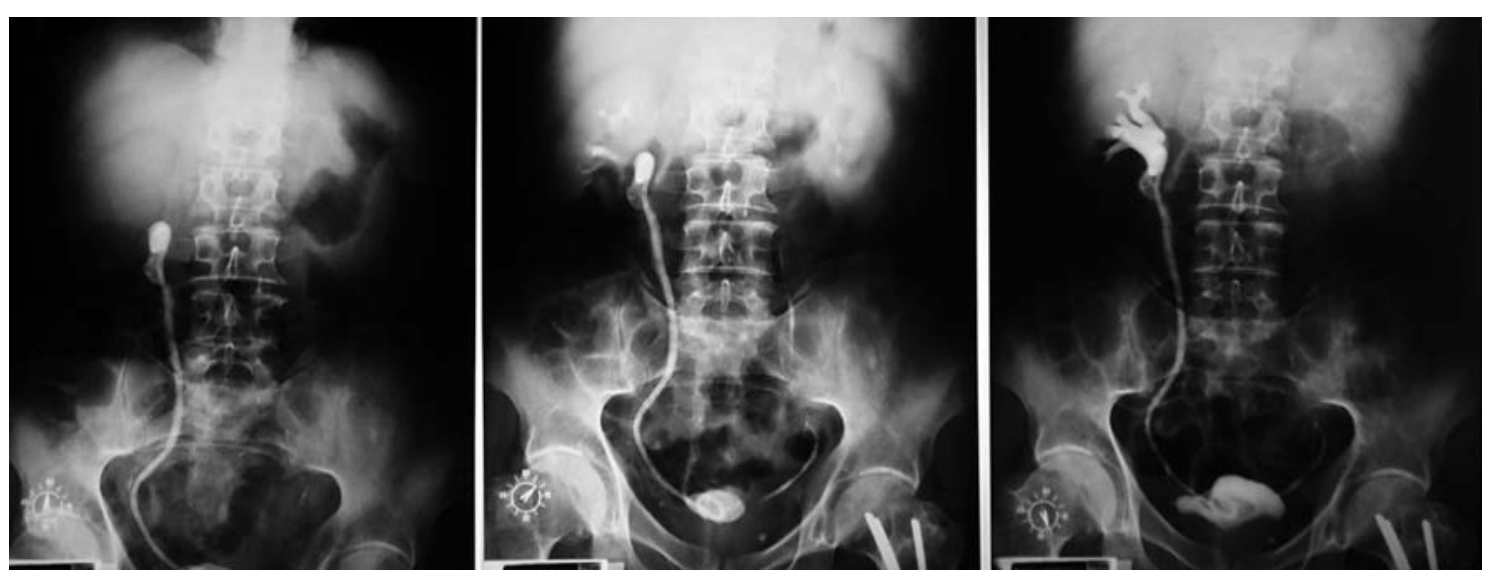

FIGURA 2 